\title{
Francesco Gambino
}

University of Macerata

e-mail: francesco.gambino@unimc.it

ORCID: 0000-0002-4873-5917

\section{THE NEW DIGITAL GRAMMAR IN THE CULTURE OF INSTITUTIONS}

\begin{abstract}
The paper aims to explore the phenomenon of the spread in democracy of new powers - produced by inexhaustible technological developments from the perspective of the philosophy of Institutions. It traces the original idea of democracy, in which the «government of the people» arises from the conversion of natural liberty into social and political liberty, dwells on the political and juridical meaning of authority, analyses the traditional instruments used to condition human opinions and behaviours, and reconstructs - in light of this itinerary - the functioning and new grammar of the digital order. What opens before us is a fluid and disorganized scenario, dominated by digital systems, algorithms and artificial intelligence, that draws the attention of philosophers and sociologists, jurists and scholars of language and of anthropology. The old single order, outlined by the political and juridical machine of the modern State - which, through an aloof and solemn language, aimed to impart regularity to human behaviour and to give society direction - is replaced by multifarious models of order, each of which is generated by its own logic, practices, and autonomous control techniques. Under the omnipotence of technology, concepts such as authority, liberty, truth and power undergo a vortex of semantic transformations that penetrate a new symbolic space into human reasoning and actions.
\end{abstract}

Keywords: authority, democracy, digital, power, post-truth.

\section{Authority as the development of the concept of freedom: the original idea of democracy}

What is authority today? What concept is concealed beneath this ancient word ${ }^{1}$ ? How is it represented in our epoch? How are its features mirrored in the details? ${ }^{2}$

In the political-legal context - which is where these pages stem from the word «authority» suggests a conditioning power «on the opinions and behaviours of single individuals or groups, by whoever possesses it» (Ab- 
bagnano, 1998, p. 110). It is the power of control over the belief and will of a third party with which someone or something is vested ${ }^{3}$. The term immediately acquires significance if we evoke the traditional idea of law in the modern civilization. It could be said - albeit with some loss of nuance and emphasis - that, in this case, authority is expressed through the sovereign power of the State, which holds a monopoly over coercive power, through the singleness of the source of legislative production and the dependence of legal phenomena on the exercise of political power.

The law, from this perspective, is essential for the solidity of the political structure and it is the State that exclusively exercises the power to produce it ${ }^{4}$. It is the road that was taken at the end of the $18^{\text {th }}$ century to assure stability to an order in which the fundamental functions of the State (legislative, executive and judicial powers) were to be balanced. The State, for it to exist and last, needs a law that meets the requirements of objectivity and impersonality ${ }^{5}$ to maintain the social ties within the community.

It is no surprise therefore that, in democratic orders, originally underlying this notion of authority was the metamorphosis of the concept of liberty. Words, through their etymological roots and variations of meaning, create the world in which we live: we are always tied down by semantic constraints, by a common horizon of meanings that correspond to our needs, interests and expectations for the future. Authority, in democracy, arises from the combination of two primordial instincts of the social being: the reaction against social constraints (namely, «the freedom of anarchy») and the pretence of being equal (Kelsen, 1995, p. 45). If it is true that a ruling authority is absolutely necessary, then this authority must come directly from us and upon us befall again from above.

All men being equal, it is only from their concordant will that the foundations and the principle of authority can arise $e^{6}$.

In other words, the issue is if it is essential for a society, and all the more for a State, to have a «mandatory regulation of human relations between them» (Kelsen, 1995, p. 46). Power is manifested in the binding relationship - «mandatory regulation» - that men impose upon themselves. Here, political heteronomy lays its roots in the cultural phenomenon of autonomy. Natural freedoms are initially converted into social organization and semantically morphed into social or political freedom (Kelsen, 1995, p. 46). The flaws in the logic of this construct - such as the absence of unanimity in the enforcement of the contractual order - do not weaken the objective validity of social order for social sciences (Kelsen, 1995, p. 49). Democracy is accomplished by approximation. Achieving it means coming close to its original ideal. Therefore, it forgoes unanimity and tolerates major- 
ity decision-making (Kelsen, 1995, pp. 49-50). Ideas and reality are never aligned. The distance - the antithesis and the dialectics - between the ones and the other indicate a compromise that is instrumental to the common purpose.

\subsection{The rule of the people and the sense of the Institutions}

The word «democracy» (from the Greek $\delta \eta \mu o x p \alpha \tau i \alpha$, composed of $\delta \tilde{n} \mu o s$

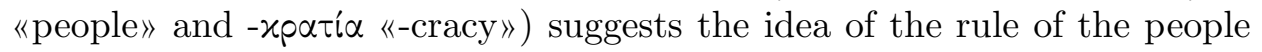
over the people. The people, however, is not a group of individuals but an invention: a system of individual acts, created and regulated by a legal order (Kelsen, 1995, p. 59). The «rule of the people» does not mean a «government that acts in the interest of the people» (Kelsen, 1995, p. 193). In actual fact, a mass of individuals with different economic and cultural backgrounds do not and cannot express a unity of concrete wills that can be said to be identical or homogeneous. What appears to be artificially united is naturally divided. The will of the people is not homogeneous. They can only express strategies, orientations, and guidelines detectable through the laws of statistics. Quantitative tendency indexes that lead us to presume, through much sought-after data, the existence of a certain regularity. The «rule of the people», in a direct or representative democracy, only means a government in which the people participate through the creation and application of «general and individual provisions of the social order that constitutes the community» (Kelsen, 1995, p. 195). An underlying basic necessity emerges - from an anthropological perspective - of «Man as a being who acts»(Gehlen, 2016, p. 22): that of keeping together the things on which social man acts. The idea of freedom that, coordinated with the principle of equality, is generated in democracy, objectivates and takes shape in Institutions.

The original absence of constraints (the refusal of obligations, anti-social impulses, the freedom of anarchy) makes Man changing and vulnerable and gives insight into the fundamental meaning of institutions, which express the «capacity of every possible duration and continuity of what is loftiest in Man» (Gehlen, 2016, p. 22). For a Man dominated by a multitude of impulses, the «austere institutional authority», gains full autonomy and «assumes for him the priceless value of certainty» (Rasini, 2016, p. 12). Institutions (the State, the family, economic and legal authorities, etc.), by constituting an original space in social living, «transform into a power» that acts upon the individual by enforcing its own laws (Gehlen, 2016, p. 20) and its own discipline ${ }^{7}$. Here, authority is almost synonymous to certainty, stability and order. 


\section{The Authority's instruments of control}

The conceptual line described assumes a circular form. Democratic institutions, generated by the primordial need of autonomy, turn back on the effective individual wills in order to make them homogeneous. The great value of the certainty expressed by the authority must be reflected onto the system of individual acts of which the people consist. Otherwise, it would be an empty certainty in which nothing would correspond to the reality pursued by power. What authority wants is the continuity, predictability, and calculability of human behaviour. Political power, in order to implement goals and programmes, needs for law to act on human behaviours as an orthopaedic device (Carnelutti, 1951, p. 71).

The instrument through which to obtain - or presume to obtain - obedience - or, if you like, abidance by the rules and spontaneous compliance by individuals - is the causal principle. As human material is an immaterial flow of psychic elements, the only way of harnessing and immobilizing it is by using a given language. You need to talk in a certain way to the people that you want to act in a given way. Violence is, so to speak, denaturalized in the legislative word of the government majority. This word specifically belongs to a prescriptive language to oblige people to do. Authority can thus condition human will as long as there is a yardstick that detects and evaluates given behaviours and follows them up with legal consequences, as in a law of natural causality (rights, obligations, faculties, etc. $)^{8}$.

\subsection{The linguistic machine of the law}

What emerges is a technique of social control. This technique arises from the presupposition that Man - whose behaviour is regulated by the law - considers the forced deprivation of a good (life, liberty, economic assets) as an «evil that they try to avoid» (Kelsen, 1952, p. 69). In the same way, the conferral of a reward following a given behaviour, is considered to be an incentive to make Man comply with the behaviour induced or prompted by the reward. This methodological approach gives rise to an underlying presumption. «Punishment and reward are given only because it is presumed that fear of punishment can be the cause that holds Man back from committing a crime and that the desire for reward can be the cause that drives Man to perform an act of heroism» (Kelsen, 1952, pp. 222-223). The law relies on fear and desire in order to function and impose a direction to the behaviour of a plurality of individuals. In this context, normative command, which is the will to give shape and content to the will of other people, takes the form of a hypothetical judgment ${ }^{9}$. 
This is the conditioning power of the law. This is where the whole certainly of the law lies: in the individual's need to «know what he has to do» (Cotta, 1991, p. 497). In this perspective, in order to turn into an efficient linguistic machine - the autonomous cause of a collective movement ${ }^{10}$ the law must be able to result visible, certain and rational.

The clear, technical language of ordinary laws on the one hand fulfils the need to provide an effective «support to 'people's' claims» (Irti, 2016, p. 75) and, on the other, creates a certain distance from those who contributed to establishing the social order for the community in which they live.

The criticisms to logical neopositivism and the analysis of language that pervaded the Italian legal culture in the 1950s «do not undermine the linguistic essence of the law, as it has been established in the modern age and in the legislative State» (Irti, 2016, p. 76). The intertwining of «capitalism and legal rationality extends beyond the crisis of the modern State» (Irti, 2016, p. 77). The former requires a high degree of semantic unambiguousness and linguistic accuracy and aspires to a law that is as calculable as a machine. The calculability of the law can pre-empt and calculate the legal consequences of human behaviours. By linking given consequences back to certain facts, legal norms make it possible to diagnose the single case and predict the judicial decision.

Along this line of thought, the lever of the effectiveness of a legal order - if you prefer, of the expected outcome - consists of the psychological elements of fear and desire. And this is the field of action of authority. The pathos of distance opens between the individual and the authority, this austere institution ${ }^{11}$. We are not given to know how much energy is exerted by these constructions to orient human action, to express an effective control ${ }^{12}$, and to rightfully concretize into an authority. Culture, education, propension to imitate or to repeat - rules etched in our DNA - have always autonomously conditioned Man's actions, independently of the command imparted on him (Sacco, 2015, pp. 115-131). More generally, it is honestly impossible to understand what is the cause and what is the effect. The problem of the «incalculable law of complexity», of the «invisible power of things»: «the complicated and ever-complicating effect of what everybody does (and of what is done in and by them)》(Sini, 2016, p. 23).

However, lacking the principle of causality ${ }^{13}$ - the inescapable element in the narration of any body of knowledge - here expressed in clear, firm and intelligible language, it is not even possible to presume to command Man's will. 


\subsection{A causal explanation of statistical phenomena and laws}

As we have already said, political and juridical authority manifests itself through an external measurement which, resulting in the connection between condition and consequence ${ }^{14}$, leads us to presume an ultimate social organization. This is characteristic of normative sciences which do not aim to know but rather to regulate society through a «chain of causation uniting the elements of their own objects» (Kelsen, 1952, p. 216). A given order (moral, religious, juridical) can be said to be effective and functional whenever the «consequence that is expected to take place in compliance with the social rule is likely to occur» (Kelsen, 1952, p. 213). It is a technique of social control that acts and leverages upon the will of men. However, in order to regulate - or presume to regulate - society, it is necessary to know human behaviour. In order to adopt a measure that can have a normative effect on men from the outside, one must know how to interpret the human material ${ }^{15}$. In social science, just as in natural science ${ }^{16}$, looms the problem of giving a causal explanation of phenomena. In the first case, they deal with natural phenomena and in the other, they explore human behaviour intended as an element of nature (Kelsen, 1952, p. 215).

Both fields of study seek empirical regularities that can be recorded by statistical laws. The appearance of discontinuity in quantum physics in the investigation of atomic systems (Agamben, 2016, p. 23) - and «abandoning the determinism of classical mechanics in favour of a purely probabilistic conception of reality» (Agamben, 2016, p. 13) - has not deprived social statistics of their value. Quite the opposite: it has extended their foundations. If it is deemed plausible that at the origin of human vicissitudes there was a «simple, invisible and unpredictable» (Majorana, 2016, p. 78) vital fact - in itself comparable to the accidental disintegration of a radioactive atom - then the statistical laws of social sciences improve their performance because they deliver an «immediate and tangible testimony» (Majorana, 2016, p. 78) of reality. The interpretation of this testimony ${ }^{17}$, given by the statistical laws of social sciences - «a special art, and not the least of the inputs in the art of governing» (Majorana, 2016, p. 78) - constitutes the condition for command and orientation measures. The problem, as has been said ${ }^{18}$, is that human behaviours prompted or imposed by external command measures, maintain a hidden area created by a judgment conditioned by the individual's whole system of beliefs ${ }^{19}$. The probability estimate, on which the effectiveness of the legal order is built (Kelsen, 1952, p. 213), combines with the probability estimate made by the people subjected to the order. 


\section{The new powers and technological development}

Today, power is seen to be marked by deep changes. It is a disfigured face. It draws the attention of jurists, sociologists and philosophers, and scholars of the language and of anthropology. The erosion of the juridical capacity of the State - with the law deprived of a centre and of an apex (Teubner \& Fischer-Lescano, 2005, p. 159) - acts in many different directions. The new juridical pluralism - which multifariously penetrates political initiatives, the sources of law and judicial decisions - comes from the grassroots and, in a subjective conception of the law ${ }^{20}$, disavows the singleness of the source of law, the dependence of juridical phenomena on the exercise of political power and the traditional notion that it is the State that exclusively wields the power to produce laws.

A single order is replaced by a multitude of models of order, «each generated by a series of relatively autonomous practices» (Bauman, 2007, p. 14).

While private individuals organize their relationships with rules unbound from the legal order, national and international private institutions (in the economy, science, technology, education and medicine) multifariously and factually come to compete with the principle of the single source of $\mathrm{law}^{21}$. We are witnessing a phenomenon in which freedom is converted into power. Freedoms, «even while defending and protecting themselves against public power, are power in and of themselves or the source of power» (Irti, 2013, p. 13). Expanding freedoms, which concerns the relationship between us and the others, is never innocent: «it marks the distinction or antithesis between the holder of this legal power and the others» (Irti, 2013, p. 14). These powers establish - with respect to the unfolding facts - their own link of causation, new correlations of events, and their own chain of effects. The relationship between the condition and consequence established by the new domineering powers, does not so much express having to be as much as having to happen. It is not difficult to see how, in the recent past, single cases, images, and events, even far from the political agenda disseminated in social networks or in the mass media - can constitute the ultimate impulse for national, European and international institutions to promote an initiative.

Democracy is caught in the conflict between antagonist forces that, in order to prevail, «resort to the force majeure available to man, which nowadays is represented by technology, guided by modern science ${ }^{22}$ : «an effective force», intended as «the form of the effective production of specific and particular goals $\rangle^{23}$. In this scenario, the great technological revolution aimed at making human material redundant ${ }^{24}$ in the widest variety of sec- 
tors (military, economic, financial, medical, etc.), is destined to give the concept of authority a new face. It is sufficient to think of «hi-tech forces consisting of unmanned drones and computer viruses» that «are replacing the mass armies of the $20^{\text {th }}$ century» (Harari, 2019, p. 376), of most of the stock exchange transactions being managed by digital algorithms (Harari, 2019, p. 381), of the Watson artificial intelligence system, which features an extraordinary databank and is now prepared to diagnose diseases (Harari, 2019, pp. 384-388).

Among the new powers built on algorithms, there is the blockchain technology, whose full functionality will depend not only - and not mainly - on the legislative initiatives of political institutions but above all on the concrete possibility of zeroing the risk of data leakage, external manipulations and hacking.

These powers are qualified by scholars of the sociology of law as fullfledged private legal «regimes»(Teubner, 2013, pp. 381-382). The system that stands out among these regimes - as it is in contrast with traditional political and constitutional powers - is the lex digitalis (Teubner, 2013, p. 381).

\section{The grammar of the digital order}

The digital order ${ }^{25}$ marks the waning of institutions founded on the characteristic stability of the Earth (Han, 2016, $4^{\text {th }}$ ed., p. 67). It constitutes a fluid reality, untouched by the discipline and logic of State authorities, and outlines an autonomous symbolic space crowded with a mass of isolated individuals, and thrives and feeds on algorithms and digital devices.

The psychological atmosphere in which we live increasingly feels the effects of the widespread and pervasive use that people make of the digital world.

Actions are replaced by «operations», «actomes», which means «automated actions within a widely automated process», deprived of a «temporal and existential extension» (Han, 2016, $4^{\text {th }}$ ed., p. 68). It is an order in which the notion of slow and emphatic thinking - hesitating and lingering - yields to computational processes intolerant to system inefficiencies or slowdowns. We are in the presence of a new language that, by also feeding on our opinions, proposes itself as an entity that forms human thought and actions ${ }^{26}$. What is the digital grammar, i.e. the set of rules - of the game - that constitutes the specific way of being and functioning of the digital language or, if you prefer - of reality?

In jotting down these pages, some regulatory principles emerge. 


\section{a) The absence of the pathos of distance}

We are in the presence of a public space - disguised as a private space - and in itself oriented towards the consensus of the audience ${ }^{27}$. Every user «thinks, more or less consciously, of those that he tries to persuade and who make up the audience» (Perelman, 1966, p. 21). It is a space exposed to the look of others. It is a space that, in all the new rhetoric forms of social living (Mortara Garavelli, 2011, pp. 26-27), is pervaded by a continuous tension towards the effectiveness of the persuasive effort. It is this absence of the pathos of distance that leads to mixing the public with the private sphere (Han, 2016, $4^{\text {th }}$ ed., pp. 11-12). It is a new symbolic space that reduces the expressive capacity of common language and encourages - with signs, images, variations in the meaning of concepts - the digital language. The public figure and the private individual all use the same tools, speak the same language, adopt the same communication techniques. Political authorities have abandoned formal and solemn forms of language and use posts, tweets, video messages ${ }^{28}$ to set forth propositions, programmes and initiatives. These communication techniques and processes reduce the distance between the public figure and the private individual, in sharp contrast with the way that authorities once traditionally acted ${ }^{29}$. It is the waning of the linguistic form of sovereignty.

\section{b) Conglomerate of isolated individuals}

Who are the users of the digital order? Who makes up the people of this symbolic space that, lured by the possibilities offered by machines, subject themselves to the rules of digital grammar, unknown logics and invisible powers?

The people, in a democratic order, are the subjects and objects of power. They participate in the creation of the State order to which they are subjected. It is not a group of individuals but a system of individual acts, determined through regulatory unity (Kelsen, 1995, pp. 58-59). It is an invention arising from a juridical fact. The profile of participation - in the digital context - can be inferred from the new platforms of direct democracy that aspire to manage parties through their electorate and to enable party members to participate in the life of the party. Generally speaking, the «people» in the digital order have no binding elements between individuals, who remain isolated (Han, 2016, $4^{\text {th }}$ ed., p. 22). Rather, they make up a digital horde in which, lacking the spirit of a crowd, individuals fail to develop a notion of $U s$ (Han, 2016, $4^{\text {th }}$ ed., pp. 22-23).

Precisely this being a conglomerate of separate individuals expresses the conditioning force of authority, which can act on this fragmented re- 
ality. A reality that, for a host of widely differing reasons, can effectively be composed into single digital identities that are traceable, locatable and controllable. From the point of view of individuals, it is not a freedom that is itself converted into power but a freedom of isolated individuals who - together with other individuals - assign to third parties the power to supervise, control and condition. The voluntary entry of data hands over to others knowledge that lies beyond our scope of control (Han, 2016, $2^{\text {nd }}$ ed., p. 17). This body of knowledge extends to knowing the dynamics of social communication (Han, 2016, $2^{\text {nd }}$ ed., p. 21). Extraordinary technological developments give Power new features. Here, the control of human behaviours is free of the intellectual cost of normative command insofar as artificial intelligence makes human activity redundant in many contexts. The conditioning exerted by opinions and convictions finds in digital reality the place in which to track individual habits, inclinations and orientations. Conversely, it is a place in which the capacity of judgment appears to be weakened by an excess of information. This makes the step to exerting an action on people's consensus very short. We are faced with «omniscient oracles» who are destined to become «sovereign» (Harari, 2019, p. 416).

\section{c) Metamorphosis of the concept of liberty}

It can happen - in the digital order - that some categories, that are essential for human thinking and acting, change meaning. This is the case with the concept of freedom. What appears to be for the user an instrument of freedom, communication, possibilities that can be exercised, converts into a place of submission (Han, 2016, $2^{\text {nd }}$ ed., p. 9). Freedom - which is authentically realized within a being together with another being - is used to the point of being converted into a coercive reality ${ }^{30}$. The power is no longer disciplinary but takes on a «permissive form», uses the freedom of others in a subtle and intelligent way and avoids visibility (Han, 2016, $2^{\text {nd }}$ ed., p. 24). The digital order machine does not operate - as was customary with the machine of traditional legal order - with obligations and prohibitions, chains of causation, sanctions and rewards. It is an invisible power that appears in a liberal and benevolent guise ${ }^{31}$.

The mere fact that a network is a fragmented reality of isolated individuals exposes it to an intelligent power that records our thoughts, conscious or unconscious (Han, 2016, $2^{\text {nd }}$ ed., p. 25). It is a power that feeds on the practices and expressive forms of freedom. 


\section{The contaminating action of words}

It is truly no longer a surprise that modern-day democracy is permeated by manipulative information. The excess of opinions on social media - which weaken critical judgment - and the loss of trust in institutions as reliable sources of information, pave the way for fake news (D'Agostini \& M. Ferrera, 2019, pp. 66-67). In this flawed atmosphere, it could also happen - as in the famous play by Henrik Ibsen - that whoever takes up arms and fights «against a society founded on deceit» is declared an «enemy of the people» ${ }^{32}$ by the assembly of citizens. We can backtrack to the crisis of democracy in Athens, which started with the Peloponnesian war, in order to understand how the need for truthful discourse can be detached from the language and culture of the time (D'Agostini \& Ferrera, 2019, p. 64). Thucydides tells us that public discussions lost shared meanings and that words were only used for opportunistic reasons. Democracy degenerates into what Plato called «theatrocracy», the «government of the theatre, in which the logos stops referring to what is true, good and beautiful» (D'Agostini \& Ferrera, 2019, p. 64).

The reality of the Web appears to be devious and fragmented. On the one hand, it enhances propositional and participatory instruments and, on the other, it generates the problem of opinion formation and decisionmaking. In this climate, the phenomenon of post-truth takes hold and spreads. This phenomenon is destined to weaken the democratic system that grounds its good functioning on serious and independent information.

\subsection{Digression on the false notion of post-truth}

The word «post-truth» is defined as relating to or denoting circumstances in which objective facts are less influential in shaping public opinion than appeals to emotion and personal belief (from the Oxford English Dictionary which named «Post-Truth» word of the year 2016). The term is improper and misleading, destined to fluctuate between contradictions, sense variations, operational contexts. We could begin by questioning the newness of the phenomenon that the neologism intends to designate. The dissociation between personal convictions and «objective» and controllable realities spans across the most problematic history of scientific and philosophical thought. Across the centuries, humanity lived in the firm belief that the Earth was flat, immobile, at the centre of the world and that the Universe was identical to itself. We then learned that the Earth is round, that there are quarks, black holes, particles and fields that move in space; that the Universe is multiform, rutilant, continuously expanding (Rovelli, 2014, p. 9). 
Scientific thought, as if chained to the wall of Plato's dark cave, proceeds through shadows, images and perceptions up to the moment it succeeds to describe the world in a way that is more functional to our look. By way of example, Michael Faraday, in developing Newton's intuition on the presence of «some agent» capable of explaining why far-away bodies attract and repel each other, elaborated the idea of «lines of force» that, in the mathematical version suggested by Maxwell on the behaviour of electrical and magnetic fields, would pave the way for all the modern technological applications to communications (Rovelli, 2014, pp. 52-55). In other words, «the more we discover, the more we realize that what we still do not know is even more than what we have understood» (Rovelli, 2014, p. 9).

Conversely, philosophical discourse would immediately bring out the three fundamental approaches that have characterised the history of philosophy and which, to different extents, embody support or opposition for «subjective» certainties and «objective» truths, between human knowledge and the world that depends on it, between beliefs and reality (Severino, 2011, p. 12). From a post-modern perspective, in which reality appears to objectively dissolve into subjectivity, and where the possibility of accessing the world is exercised at the level of pre-cognizance (of «equipment», wrote Kant) and of our historical and natural language (Vattimo, 2012, p. 27). It would not be inappropriate to root post-truth in a famous excerpt from Nietzsche's posthumous notes: «it is precisely facts that do not exist, only interpretations». Thus, this perspective would have precisely personal convictions and suggestions qualifying facts as being objective, shaping their qualities and building their signification.

However, this quick overview of scientific and philosophical thought within which the concept of post-truth is destined to fade and dilute overshadows what originated the success of the word, which arose from its topicality. As is widely known, the use of the term became widespread concomitantly to the United States election results of 19 December 2016 and the planned withdrawal of the United Kingdom from the European Union (Brexit) following the referendum of 23 June 2016.

For some, the idea has taken shape that in both cases - i.e. the election results - emotions prevailed over popular consent, which therefore resulted to be less likely to be conditioned by objective and verifiable data and, to a certain extent, insensitive to the truthfulness or falseness of the information available (for example, the undocumented news which was later denied of the excessive costs borne by the United Kingdom through the contribution paid to the European Union). This gave rise to the doubt, from the semantic point of view, of whether to replace the prefix «post» with «beyond»: so, 
not «post-truth» but «beyond the truth». So, not «post», which projects you into a subsequent point in time, but rather a meta-truth, a «superseding» (Biffi, 2016, p. 1ff.), insofar as public opinion moves in directions that are aloof from the force of persuasion of «objective» facts, along a mobile plane: precisely that of the impulse of emotions and personal convictions.

The era of digital psycho-politics, which feeds on big data, smartphones, likes and posts, has created a new relationship between power and liberty, reducing people's capacity of judgement and influencing their psyches at a pre-reflection stage (Han, 2016, $2^{\text {nd }}$ ed., pp. 21-22). As we have already said: the reality of the Web appears to be devious and fragmentary. On the one hand it multiplies instruments and the capacity to participate; on the other, it amplifies the problem of opinion formation and decisionmaking processes. It can thus come about that some information, even if patently false, is welcomed and shared by users because it complies with their convictions and expected sense (Ainis, 2017, p. 1ff.).

In this perspective, it becomes all the more necessary to have serious and independent information, supported by trained and expert reporters endowed with a sense of doubt and who are capable of delving into the news and separating true facts from alternative facts (de Bortoli, 2017, p. 15). This is the only way - paved by others - that public opinion, dumbfounded by the occult impulses of the Web and by digital anonymity, can once again act as the «authentic backbone of democracy» ${ }^{33}$.

In this setting surfaces the element that is implicit to the expression post-truth which, upon a more careful look, does not concern the production of false news disseminated on the Web, in newspaper columns, and in political campaigns, but a different underlying phenomenon, namely the way of receiving or refusing said information. The prefix «post» conceals and omits what would instead be useful to make explicit, namely the psychological and emotional roots of mass judgment. What remains self-evident - and that, in my opinion, characterizes the overall sense of the phenomenon - is the inherent, unknown and at times unwanted logic underlying the formation of a collective mindset and behaviour (in the cases mentioned, socially and politically relevant decisions). In particular, it alludes to a widespread disinterest for the truth, an attitude of indifference, of surrendering to disillusion. It introduces the idea of a general indolence in acquiring and verifying information useful to making informed decisions. Beneath this deep sense of inertia emerges an enfeebled will that, from this point of view, we could say drifts into a form of collective abulia. It would be wiser, at this point, to speak not of post-truth but of psycho-truth (or, if you prefer, of psycho-reality). This latter expression would be more fitting in expressing 
a collective psychic phenomenon associated with a certain idea of «truth» (or of «reality»). In this context, dominated by impulsive judgments and unfounded conclusions, what is left of the «truth» is destined to flow back into what is presumed to be logic, for the mere fact of having decided to make a choice.

\section{The authority of contemporaneity}

In this paper, we have defined the notion of authority as the history of the ownership of a control that is exercised over human convictions and behaviours. In our epoch, authority is presented as resulting from the unavoidable development of technology into new forms driven by algorithms, artificial intelligence and digital systems. It is expressed through the power to subrogate human activity, to make free use of data and information, to know, monitor and condition habits, inclinations and orientations of single individuals. It is a radical transformation of human history that already allows us to prefigure the future. It will be our linguistic machine - our culture - that will defend and preserve the places of truth and human activities deemed to be indispensable.

\section{N O T E S}

${ }^{1}$ From the Latin auctoritas -atis, derived from auctor-oris «author».

2 «What matters the most» - wrote Leo Spitzer (1967, p. 6) - «is not the fact that a certain concept is of fundamental importance in a given civilization but the way in which it is represented in different epochs: the way in which its influence was felt in the details».

3 Today reference is made to anonymous global communication processes (the «anonymous template») in respect to the violation of fundamental rights (Teubner, 2013, pp. 388390).

4 This is the interpretation given to the statism and legalism of 'modern' law by law historians (Grossi, 2017, p. 73, which focuses on the «negative results that it caused in the unfolding of the Italian legal experience»).

5 The formula of the Rechtsstaat, which comprehensively and generically indicates the fact that the State is subjected to the Rule of Law and that, in the relationship between the State and citizens, it claims the necessity - perceived by Silvio Spaventa in his famous speech on Justice in the Administration (Giustizia nell'amministrazione) of 7 May 1880 - of a «certain, clear and thorough public law» conducive to the «democratization of the life of the State» (Spadolini, 1993, p. 5). In this historical context, justice in the Administration marks a crucial turning point in the making of the modern State in the Unified Italy (Ghisalberti, 1991, pp. 149-150).

${ }^{6}$ Nicola Abbagnano (1998, p. 111) recalls that the first great propounder of this doctrine - conceived by the Stoics - was Cicerone. 
7 «Discipline» - one of the great technical inventions of the 18th century - «'makes' individuals; it is the technique of a power that is conferred upon Men, both as the objects and as the instruments of its exercise». It is by virtue of a «hierarchical, continuous and functional supervision» that «the disciplinary power becomes an integrated system» (Foucault, 1993, pp. 186, 193).

8 It could also be added that - depending on the different orientations - the mechanisms of a law thus conceived aim to heighten the economy to the level of ethics, to work like a technique of social control and achieve a transcendent idea of justice or, from a sociological perspective, to intercept a progressive rationality in history in which legal institutes take shape and stabilize over time.

9 For example, the person who purchases a good stipulated through a sale contract, in actual fact performs a fact that is contemplated in a normative case and, pursuant to Art. 1498, Para. 1, of the Italian Civil Code «is held responsible [has the obligation] to pay the price». The word «obligation», stripped of semantic references, is the consequence and falls under the category of effects, a 'have to' that takes place in the relationship between a judgmental (must) and an ontic (is) category.

${ }^{10}$ In one of his writings, Carlo Sini (2016, p. 34) says: precisely because «the linguistic machine reveals the stimulus towards a common reply (this sound means for everybody that there is a prey at hand; this colour on someone's face indicates to everybody that we are at war, etc.), the language moves bodies accordingly and in this sense is autonomous».

11 The expression «pathos of distance»- which appears in the chapter entitled What is Noble by Friedrich Nietzsche - was used when referring to the digital world - about which I will be speaking later on in this paper - by Byung-Chul Han, 2016, Im Schwarm. Ansichten des Digitalen (2013), pp. 11-12.

12 Benedetto Croce wrote about the collective movement in a military exercise, comparing it to the problem of complying with the law: «Taking a broad look from afar, there seems to be uniformity: looking close up, you see differences» (1908, p. 339).

13 This principle, as we have already said, shares the same grammar - a hypothetical judgment - as the principle of imputation (Kelsen, 1952, p. 216).

14 Unlike causality, the chain of causation indicates a relationship between the condition and the consequence that is present in a moral, religious or juridical law and that is established by human or superhuman acts. This is «the specific character of the connection between the condition and the consequence that is expressed by the term 'duty'» (Kelsen, 1952, p. 217).

15 Indeed, in a typically modern view of the world, «the effectiveness of control depends on an adequate knowledge of the 'natural' order» (Bauman, 2007, p. 14).

16 On the analogy between physics and social sciences substantiated by the principles of quantum physics, see the contribution by Ettore Majorana entitled Il valore delle leggi statistiche nella Fisica e nelle Scienze sociali, published posthumously in the magazine Scienza (vol. 36, 1942, pp. 55-66), now in the addendum to the book by Giorgio Agamben (2016, pp. 55-78).

17 According to Giorgio Agamben (2016, p. 19), «to interpret» here means «rule»a verb quoted in the page by Majorana - thus making statistical laws of social sciences aimed not at knowing but at regulating society, «at 'governing' social phenomena».

18 See, ut supra, $\S 2.1$.

19 «Unfortunately, there cannot be a simple formal procedure to evaluate the compatibility of a series of probability estimates with the over-all system of beliefs of the person making the estimate» (A. Tversky \& D. Kahneman, 2017, pp. 593-594). 


\section{Francesco Gambino}

20 Sergio Cotta (1985, p. 14), quoting Vico, recalls the unveiling of the sense of a «birth» (of the law), «more than historic, ontological, meaning required by the very being of man», in Il diritto nell'esistenza, Linee di ontofenomenologia giuridica, Milan, 1985, pag. 14.

21 These systems «tend to make an increasing use of sources of law of their own, namely sources that lie beyond the sphere of national legislative production and of international treaties» (Teubner, 2013, p. 381).

22 This is what the philosopher Emanuele Severino replied to the question posed by Italian Prime Minister Giuseppe Conte (in the interview of 14 April 2019 accessible on the website: gazzettafilosofica.net).

23 See Emanuele Severino (2000, p. 675) where - in a dialogue with Natalino Irti he takes great care in clarifying the use of the adjective «indefinite» in a proposition contained in the book titled Il destino della tecnica: technology is an «indefinite increase in the capacity to achieve goals, which means an indefinite increase in the capacity to fulfil needs».

24 See, that the three threats to liberal philosophy and to the idea that the free choices of man, unique and unrepeatable, are «the origin of the last authority» (Y. N. Harari, 2019, p. 373).

25 With reference to the lex digitalis, the notion of digital order - enunciated by ByungChul Han [Im Schwarm. Ansichten des Digitalen (2013), 2016, p. 67] as a sign of the distance from the earthly order - appears to be more fitting to the reality described herein. If we were to observe the phenomenon through the lens of the general theory of law, we would see an organized structure, an institution, "the very position of society» (Santi Romano, 1962, p. 27). Therefore, not an abstract principle or an ideal quid, but rather «a real, effective entity» (Barberis, 2011, p. 352).

26 Wilhelm von Humboldt's insight on the issue of the inflow of language on the mind, are echoed in the pages written by Guy Deutscher (2016, pp. 151-158).

27 In the new rhetoric developed by Chaïm Perelman, the audience is defined as «all those on whom the speaker wants to exert his influence through his argumentations» (1966, p. 21).

28 See, on the issue, F. D'Agostini \& M. Ferrera (2019, p. 66). The Italian Council of State (Sect. VI, 12-2-2015, N. 769) devoted its attention to the issue, albeit in an aside: «The Council observes that the acts of the political authority» (...) «must in any case always be realized in the due form typical of the activities of the public administration (...) also and even more so in the current epoch of mass communication, messaging, tweets, followers and more, arising from the new technologies and the new pervasive modes of communicating political activity».

29 «Today, in times of democracy, power loves live public exhibitions and the mass media but tends to assume behaviours that are as common and unaffected, informal and unpretentious as possible» (Sini, 2016, p. 21).

30 See Byung-Chul Han (2016, $2^{\text {nd }}$ ed., pp. 9-10), which hints at innner obligations and self-imposed constraints.

31 See Byung-Chul Han (2016, $2^{\text {nd }}$ ed., p. 25), which adds that «the like is its sign: while we consume and communicate, actually while we click on like, we submit to a domineering relationship».

32 This is the fate of Doctor Thomas Stockmann, a physician in the city's thermal baths, animated by the vigour of publicly denouncing the infections provoked by the thermal water. Ibsen's An Enemy of the People - written in 1882 and staged for the first time in 1883 - is a manifesto of modern times.

33 See Ferruccio de Bortoli (2017, p. 14), which quotes an expression by Giovanni Sartori. 


\section{R E F E R E N C E S}

Abbagnano, N. (1998). Dizionario di filosofia, $3^{\text {rd }}$ edition, updated and extended by G. Fornero. Torino: Utet.

Agamben, G. (2016). Che cos'è reale? La scomparsa di Majorana. Vicenza: Neri Pozza Editore.

Ainis, M. (2017). Ecco l'era della solitudine di massa. La Repubblica - 14 ottobre 2017.

Barberis, M. (2011). Santi Romano, il neoistituzionalismo e il pluralismo giuridico. Materiali per una storia della cultura giuridica, n. 2, pp. 349-360.

Bauman, Z. (2007). Legislators and Interpreters: On Modernity, Post-Modernity and Intellectuals, Italian translation by G. Franzinetti. Turin: Bollati Boringhieri (Original work published 1987)

Biffi, M. (2016). Viviamo nell'epoca della post-verità?, the contribution can be consulted on the website of the Accademia della Crusca - 25 novembre 2016.

Carnelutti, F. (1951). Teoria generale del diritto, $3^{\text {rd }}$ Ed. Rome: soc. ed. del «foro italiano».

Cotta, S. (1985). Il diritto nell'esistenza, Linee di ontofenomenologia giuridica. Milan: Giuffrè.

Cotta, S. (1991). I principi generali del diritto: considerazioni filosofiche. Rivista di diritto civile, I, 495-509.

Croce, B. (1908). Filosofia della pratica - Economia ed etica, edited by M. Tarantino. Naples: Biblipolis.

D’Agostini F. \& Ferrera, M. (2019). La verità al potere. Sei diritti aletici. Turin: Giulio Einaudi editore.

de Bortoli, F. (2017). Poteri forti (o quasi). Milan: La nave di Teseo.

Deutscher, G. (2016). La lingua colora il mondo. Come le parole deformano la realtà, Italian translation by E. Griseri. Turin: Bollati Boringhieri. (Original work published 2010)

Foucault, M. (1993). Surveiller et punir. Naissance de la prison, Italian translation by A. Tarchetti. Turin: Einaudi. (Original work published 1975)

Gehlen, A. (2016). Urmensch und Spätkultur. Philosophische Ergebnisse und Aussagen, Italian translation by Elisa Tetamo, now in L'uomo delle origini e la tarda cultura, edited by V. Rasini. Milan: Mimesis Edizioni. (Original work published 2004)

Ghisalberti, C. (1991). Istituzioni e Risorgimento: idee e protagonisti. Florence: Le Monnier.

Grossi, P. (2017). L'invenzione del diritto. Bari-Roma: Laterza.

Han, Byung-Chul (2016) Im Schwarm. Ansichten des Digitalen, Italian translation by F. Buongiorno. $4^{\text {th }}$ Ed. Rome: nottetempo. (Original work published 2013) 
Han, Byung-Chul (2016). Psychopolitik: Neoliberalismus und die neuen Machttechniken, Italian translation by F. Buongiorno. $2^{\text {nd }}$ Ed. Rome: nottetempo. (Original work published 2014)

Harari, Y. N. (2019). Homo deus. A Brief History of Tomorrow, Italian translation by M. Piani, Florence-Milan: Bompiani. (Original work published 2015)

Irti, N. (2013). Tramonto della sovranità e diffusione del potere. In A. Febbrajo \& F. Gambino (eds.), Il diritto frammentato (pp. 3-22). Milano: Giuffrè.

Irti, N. (2016). Un diritto incalcolabile. Turin: G. Giappichelli Editore.

Kelsen, H. (1995). Das Problem des Parlamentarismus, Italian translation by Bruno Fleury, now in La democrazia, edited by M. Barberis (pp. 153-391). Bologna: Il Mulino. (Original work published 1924)

Kelsen, H. (1995). Vom Wesen und Wert der Demokratie, Italian translation by Giorgio Melloni, in La democrazia, edited by M. Barberis (pp. 43-152). Bologna: Il Mulino. (Original work published 1929)

Kelsen, H. (1952). Reine Rechtslehre. Einleitung in die rechtswissenschaftliche Problematik, Italian translation by R. Treves, Turin: Giulio Einaudi editore. (Original work published 1934)

Majorana, E. (2016). Il valore delle leggi statistiche nella Fisica e nelle Scienze sociali, published posthumously in the magazine Scienza (vol. 36, 1942, pp. 55$66)$, now in the addendum to the book by G. Agamben, Che cos'è reale? La scomparsa di Majorana (pp. 55-78). Vicenza: Neri Pozza Editore. (Original work published 1942)

Mortara Garavelli, B. (2011). Prima lezione di retorica. Roma-Bari: Laterza.

Perelman, C. (1966). Traité de l'argumentation. La nouvelle rhétorique, with Lucie Olbrechts-Tyteca, Italian translation, with a preface by N. Bobbio. Turin: Einaudi. (Original work published 1958)

Rasini, V. (2016). Gehlen, la cultura, le istituzioni, introduction to A. Gehlen, L'uomo delle origini e la tarda cultura (pp. 9-13). Milan: Mimesis Edizioni.

Romano, S. (1962). L'ordinamento giuridico, $2^{\text {nd }}$ Ed. Florence: Sansoni.

Rovelli, C. (2014). La realtà non è come ci appare. La struttura elementare delle cose. Milan: Cortina Raffaello.

Sacco, R. (2015). Il diritto muto. Neuroscienze, conoscenza tacita, valori condivisi. Bologna: Il Mulino.

Severino, E. (2000). Le domande del giurista e le risposte del filosofo. Contratto e Impresa, 665-679.

Severino, E. (2011). La filosofia dai Greci al nostro tempo. La filosofia moderna. $7^{\text {th }}$ Ed. Milan: Bur.

Sini, C. (2016). Inizio. Milan: Jaca Book.

Spadolini, G. (1993). Preface to S. Spaventa, La giustizia amministrativa, edited by S. Ricci. Naples: Istituto italiano per gli studi filosofici.

Spitzer, L. (1967). L'armonia del mondo. Storia semantica di un'idea, Italian translation di V. Pozzi. Bologna: Il Mulino. (Original work published 1963) 
Teubner, G. (2013). Ordinamenti frammentati e costituzioni sociali. In A. Febbrajo \& F. Gambino (eds.), Il diritto frammentato (pp. 375-395). Milano: Giuffrè.

Teubner, G. \& Fischer-Lescano, A. (2005). Scontro tra regimi: la vana ricerca di unità nella frammentazione del diritto globale, in La cultura del diritto nell'epoca della globalizzazione. L'emergere delle costituzioni civili (pp. 139190), Italian translation by R. Prandini. Rome: Armando Editore.

Tversky A. \& Kahneman D. (2017). Judgment under Uncertainty: Heuristics and Biases, Italian translation by L. Serra, in D. Kahneman, Pensieri lenti e veloci (pp. 569-594). Milan: Mondadori. (Original work published 1974)

Vattimo, G. (2012). Della realtà. Fini della filosofia. Milan: Garzanti. 